\title{
The Development of the PE Elementary School Teacher to Improve the Professional in Implementing the Learning for the Revolution Industrial 4.0 Era
}

\author{
$1^{\text {st }}$ Mu'arifin \\ Physical Education, Health and \\ Recreation \\ State University of Malang \\ Malang, Indonesia \\ mu'arifin.fik@um.ac.id \\ $4^{\text {th }}$ Rama Kurniawan \\ Physical Education, Health and \\ Recreation \\ State University of Malang \\ Malang, Indonesia \\ rama.kurniawan.fik@um.ac.id
}

\author{
$2^{\text {nd }}$ Febrita Paulina Heynoek \\ Physical Education, Health and \\ Recreation \\ State University of Malang \\ Malang, Indonesia \\ febrita.paulina.fik@um.ac.id
}

\author{
$3^{\text {rd }}$ Ari Wibowo Kurniawan \\ Physical Education, Health and \\ Recreation \\ State University of Malang \\ Malang, Indonesia \\ ari.wibowo.fik@um.ac.id
}

\begin{abstract}
The objectives of this study are as follows: (a) reviewing the procedure for developing a professional development model for PE elementary school teachers in teaching and learning, (b) producing a model for professional development that is appropriate for elementary school teachers in conducting learning, (c) examining the testing process for professional development models for elementary school teachers in conducting learning, (d) reviewing the results of testing the professional development model for PE elementary school teachers in organizing learning. According to Lee and Owens, this research on the development of physical education learning tools based on the articulate storyline application refers to the development research model. The research results by learning experts were $77 \%$, PE experts $85 \%$, elementary game experts $98 \%$, media experts $98 \%$, small group trials $84 \%$, large group trials $86 \%$. The research conclusion showed that the development of instructional media with articulate storylines was stated to have clarity, attractiveness, appropriateness, accuracy, and feasibility for students.
\end{abstract}

Keywords-Articulate storyline, Physical Education, Learning Media.

\section{INTRODUCTION}

Teachers have a position in delivering education, which plays an important role in providing the learning process. The teacher is one of the determining factors for educational achievement: the base for achieving the goals and the nation's development. The progress in education is significantly related to the advance of a country. Therefore, teacher creation is a necessity that cannot be ignored. Appreciation for the teaching profession has been carried out for a long time and will continue to be developed. The real action of teacher appreciation was conducted on December 4, 2004, with teachers' declaration as a profession. On December 15, 2005, the issuance of Law Number 14 of 2005 concerning Teachers and Lecturers. This law aims to uplift the dignity of teachers and serve as a formal juridical foundation in enhancing their professionalism. Article 8 states: "teachers are required to have academic qualifications, competencies, teacher certificates, be physically and mentally healthy, and can reach the goal of national education." In the Government Regulation of the Republic of Indonesia Number 74 of 2008 concerning Teachers, article 48 paragraph 1 states: "the development and enhancement of teacher competence ... is implemented through a system of continuous professional guidance and development (PKB)".

Physical education is an educational process that aims to develop individuals in physical activity, sports, and games, which aim to improve the motor, social, and emotional aspects of students [1]. The purpose of physical education is to develop the 
potential that is owned or to provide opportunities for students to have aspects of mental, emotional, social, physical, moral, and physical fitness [2].

The training for PE teachers that have been conducted has tended to stop in the phase during coaching (follow-up training has not been intensively done in each school), even though good coaching is done continuously. Another weakness of the coaching model often occurred so far is the lack of face-to-face time between the teacher and the supervisor. The mono-interaction coaching process (placing the teacher only as a listener), and the lack of conceptualization and skill training collaborate with peers or other parties. In recent years, new teacher professional development uses a new model/paradigm, which is planned systematically as a long-term process to encourage professional growth and development [3]. Previously professional development consisted of workshops or short-term courses on new information on certain aspects, not usually related to the teacher's work.

Coaching to face the Industrial Revolution era 4.0 is needed to form a creative, innovative, and competitive generation. One of these can be achieved by optimizing the use of technology as an educational aid that is expected to produce output that can follow or change the times for the better. To develop and spread, it requires the application of 6 main principles. The six principles are: (a) privacy and security, (b) transparency, (c) fairness, (d) reliability, (e) inclusiveness, (f) accountability. One solution for educational institutions in facing the 4.0 educational revolution is to use Big Data. Big Data itself is a technology system introduced to tackle the "information explosion" in line with mobile users' growing ecosystem and internet data. These five competencies are considered as much needed assets to compete in the era of the industrial revolution 4.0. The five competencies are: (a) critical thinking skills, (b) creative and innovative abilities, (c) good communication skills and skills, (d) cooperation skills, (e) high self-confidence.

In the perpetrator's context, school principals and supervisors training for PE teachers and supervisors who do not understand the characteristics of related disciplines. It can lead to a misunderstanding of perception about the essence of PE. The deviation is exacerbated by the model of supervision that tends to be superior to a subordinate, the dominance of initiatives by the coach, tends to be directive or authoritarian, general and broad, tends to be evaluative (find fault), directs and dictates. Adequate professionalism is a prerequisite that must be present in teachers, and therefore relevant and continuous guidance is urgently needed. The relevance of coaching is directed at the characteristics of $\mathrm{PE}$ and the personality characteristics of $\mathrm{PE}$ teachers. On an ongoing basis, it is required at the constant, dynamic, and progressive teacher coaching activities to answer professional needs that always develop from time to time.

The objectives of this study are as follows: (a) reviewing the procedure for developing a professional development model for elementary school teachers in teaching and learning, (b) producing a model for professional development that is suitable for elementary school teachers in conducting learning, (c) examining the testing process for professional development models for elementary school teachers in conducting learning, (d) reviewing the results of testing the professional development model for elementary school teachers in organizing learning.

\section{METHOD}

This research on developing physical education learning tools based on the articulate storyline application refers to the development research model [4]. The procedure used in this study consists of seven steps, namely: (1) conducting a needs analysis, (2) identifying the aspirational model desired by the PE elementary school teachers, (3) developing the initial model, (4) conducting an expert test, (5) conducting small-scale trials (testing the use of models), (6) conducting field trials (testing the application of models) using action research (action research), and (7) producing the final model.

\section{RESULT}

The data presented in this discussion includes data from 1) validation of learning experts, 2) validation of elementary game experts, 3) validation of PE experts, 4) validation of media experts, 5) small group trials, 6) large group trials.

\section{Learning Expert Validation}

\begin{tabular}{cccc}
\multicolumn{4}{c}{ Table 1. Results of Learning Expert Data Analysis } \\
\hline No. & Aspect & $\mathbf{\%}$ & Category \\
\hline 1. & Clarity & 80 & Very Valid \\
2. & Accuracy & 75 & Sufficiently Valid \\
3. & Feasibility & 75 & Quite Valid \\
\hline & Average & 77 & Sangat Valid \\
\hline
\end{tabular}




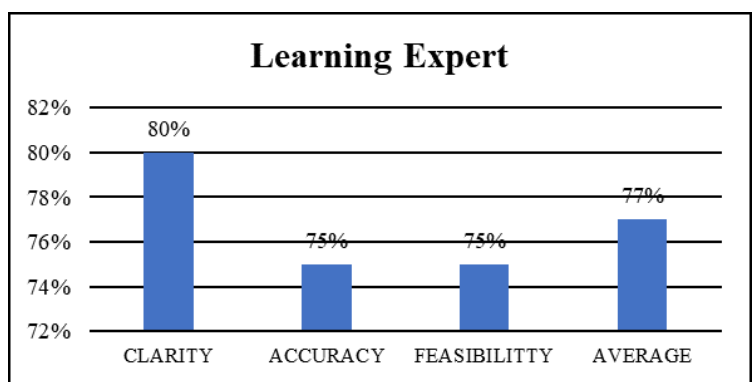

Figure 1.Percentage diagram of learning experts' justification on product development of physical education learning tools based on the Articulate Storyline application

Based on the data analysis results obtained through learning experts with a percentage of $77 \%$, these results are obtained based on the aspects that have been created. The next stage is to convert these results into a feasibility classification table, which shows that the product development of Physical Education learning tools based on the articulate storyline application has very valid criteria and is feasible to be implemented in group trials.

\section{Validation of PE Experts}

Table 2. Results of Data Analysis of PE Experts

\begin{tabular}{cccc}
\hline No. & Aspect & \% & Category \\
\hline 1. & Clarity & 100 & Very Valid \\
2. & Accuracy & 89 & Very Valid \\
3. & Feasibility & 75 & Quite Valid \\
4. & Appropriateness & 75 & Quite Valid \\
& Average & 85 & Very Valid \\
\hline
\end{tabular}

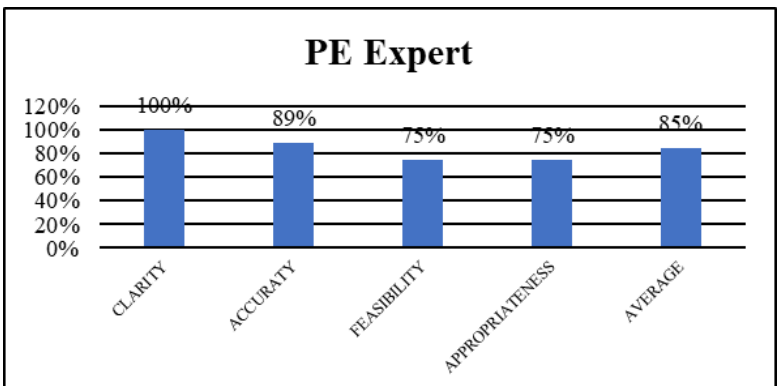

Figure 2.Percentage diagram of PE expert justification on the development of physical education learning tools based on the Articulate Storyline application

Based on the data analysis results obtained through PE experts with a percentage of $85 \%$, these results are obtained based on the aspects that have been arranged. The next stage is to transfer these results into a feasibility classification table, which shows that the product development of Physical Education learning tools based on the articulate storyline application has very valid criteria and is feasible to be implemented in group trials.

\section{Validation of Elementary Game Expert}

Table 3. Results of SD Game Expert Data Analysis

\begin{tabular}{cccc} 
& \multicolumn{2}{c}{ Table 3. Results of SD Game Expert Data Analysis } \\
\hline No. & Aspect & $\%$ & Category \\
\hline 1. & Clarity & 100 & Very Valid \\
2. & Accuracy & 93 & Very Valid \\
3. & Feasibility & 100 & Very Valid \\
4. & Appropriateness & 100 & Very Valid \\
& Average & 98 & Very Valid \\
\hline
\end{tabular}

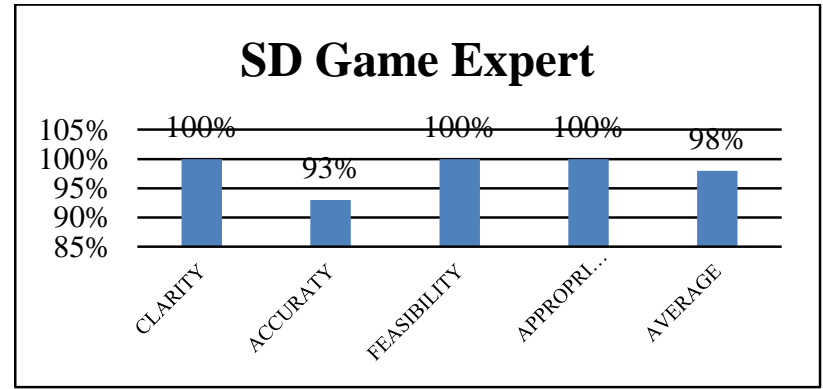

Figure 3. Percentage Diagram of Elementary Game Expert Justification on Product Development of Learning Tools for Physical Education Based on the Articulate Storyline Application

Based on the data results analysis obtained through elementary school game experts with a percentage of $98 \%$, the results were obtained based on the aspects that have been made. The next stage is to convert these results into a feasibility classification table, which shows that the product development of physical education learning tools based on the articulate storyline application has very valid criteria and is feasible for group trials.

\section{Validation of Media Expert}

Table 4. Results of Media Expert Data Analysis

\begin{tabular}{cccc}
\hline No. & Aspect & $\%$ & Category \\
\hline 1. & Clarity & 90 & Very Valid \\
2. & Completeness & 100 & Very Valid \\
3. & Feasibility & 100 & Very Valid \\
4. & Attractiveness & 100 & Very Valid \\
5. & Appropriateness & 98 & Very Valid \\
6. & Accuracy & 100 & Very Valid \\
& Average & 98 & Very Valid \\
\hline
\end{tabular}




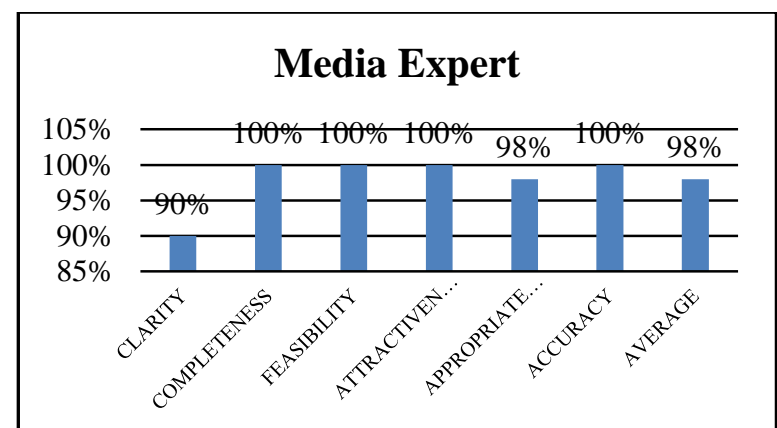

Figure 4. Percentage Diagram of Media Experts' Justification of Development Products for Learning Tools for Physical Education based on the Articulate Storyline Application

Regarding the data analysis result from the media expert, the percentage of $98 \%$ was obtained based on the aspects that have been made. The next stage is to convert these results into a feasibility classification table, which shows that the product development of Physical Education learning tools based on the articulate storyline application has very valid criteria and is feasible to be implemented in group trials.

\section{Small Group Trials}

Table 5. Results of Small Group Trial Data Analysis

\begin{tabular}{cccc}
\multicolumn{4}{c}{ Table 5. Results of Small Group Trial Data Analysis } \\
\hline No. & Aspect & \% & Category \\
\hline 1. & Clarity & 84 & Very Valid \\
2. & Attractiveness & 85 & Very Valid \\
3. & Feasibility & 87 & Very Valid \\
4. & Usability & 86 & Very Valid \\
5. & Appropriateness & 80 & Very Valid \\
& Average & 84 & Very Valid \\
\hline
\end{tabular}

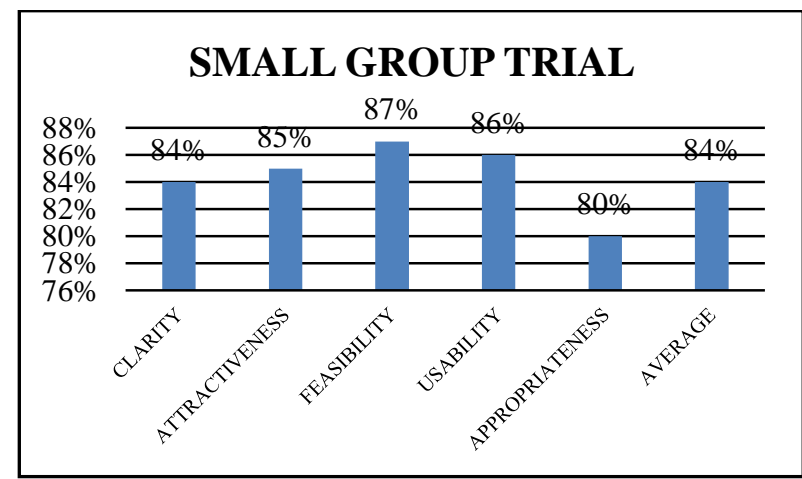

Figure 5. Percentage diagram of small group trials on the development of physical education learning tools based on the Articulate Storyline application

Based on the results of data analysis obtained in small group trials with a percentage of $84 \%$, these results were obtained based on the aspects that have been created. The next stage was to convert these results into a feasibility classification table that showed that the product development of Physical
Education learning tools based on the articulate storyline application has very valid criteria and is feasible for learning.

\section{Large Group Trials}

Table 6. Results of Large Group Trial Data Analysis

\begin{tabular}{cccc}
\hline No. & Aspect & \% & Category \\
\hline 1. & Clarity & 86 & Very Valid \\
2. & Attractiveness & 85 & Very Valid \\
3. & Feasibility & 85 & Very Valid \\
4. & Usability & 88 & Very Valid \\
5. & Appropriateness & 84 & Very Valid \\
& Average & 86 & Very Valid \\
\hline
\end{tabular}

\section{LARGE GROUPS TRIAL}

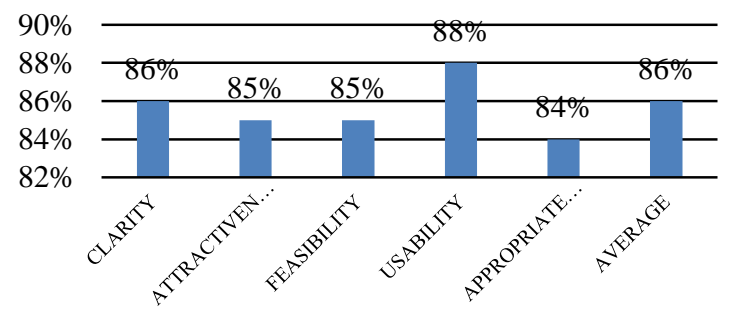

Figure 6. Diagram of Percentage of Large Group Trials on Product Development of Learning Devices for Physical Education based on the Articulate Storyline Application

Based on the result, it was obtained in large group trials with a percentage of $86 \%$. These results were obtained based on the aspects that have been made. The next stage was to convert these results into a feasibility classification table, which showed that the product development of Physical Education learning tools based on the articulate storyline application had very valid criteria and was feasible for learning.

\section{DISCUSSION}

This articulate storyline application media is beneficial for the learning process and is used to convey learning material attractively because it can use existing templates or templates according to their tastes and abilities. This articulate storyline application media was needed to share material or messages in the physical education learning process. The articulate storyline program was characterized by a menu such as a zoom button to enlarge an image. Also, a question button to see a more in-depth explanation of the material, navigation buttons in the form of next, back, and submit are always at the bottom of the screen and are automatically available in the media. 5]. The articulate storyline provides a workspace that can adapt to a template in presenting interactive and interesting material [6].

Based on the results of large and small group trials, physical education learning tools based on the articulate storyline application obtained very valid 
criteria, which means that this product was feasible and can be used in physical education learning. This product is a development product that combines several aspects, including text, graphics, images, and video from the sound. This product will be very helpful in learning Physical Education later so that Physical Education learning has a unique and interesting variety of learning that is obtained from this articulate storyline application.

The articulate storyline was software that functions as a medium of communication or presentation [7]. This form was a product of research and development as an effective and efficient learning tool. Besides, it is to support the learning process, creative and innovative media was needed to attract students to study Physical Education subjects. The development of learning media based on the Articulate Storyline curriculum 2013 can be used to obtain research results with excellent predicate [8]. The results showed that class learning results using articulate storyline learning media in social studies subjects increased by $70 \%$ compared to classes that had not used supporting media [9].

Learning media based on the application of the articulate storyline for Economy class $\mathrm{X}$ and Senior High is effective for use in learning [10]. The development of learning media based on the articulate storyline application really helps facilitate digital teaching materials [11]. This articulate storyline application product has several advantages, including the product that is easy to understand because there are pictures, writing, video, and audio. There are also some animations to increase students' interest in participating in learning, especially physical fitness, for elementary school children. The advantages of using interactive multimedia in learning are as follows: (1) Educators are required to be creative and innovative in seeking educational breakthroughs, (2) Learning systems are more innovative and creative, (3) Able to combine text, images, audio, video and animation so that they can support the achievement of learning objectives, (4) training students to be more independent to gain knowledge, (5) being able to imagine or describe material that has been difficult because it is only explained by teaching aids, (6) able to increase students' motivation when doing learning activities ( 12].

\section{CONCLUSION}

The results of research and development can be concluded as follows: (1) based on the results of the expert evaluation that the product of Physical Education learning development using articulate storyline media is stated to have clarity, attractiveness, appropriateness, accuracy, and feasibility of use by students, (2) based on the results of the evaluation of product trials in small groups obtained a percentage of $84 \%$ in the very valid category, for large group trials a percentage of $86 \%$ was included in the very valid category. The results presented that the development of learning media with articulate storylines was stated to have clarity, attractiveness, appropriateness, accuracy, and feasibility for students.

\section{REFERENCES}

[1] C. Rismayanti, "Optimalisasi Pembentukan Karakter dan Kedisiplinan Siswa Sekolah Dasar Melalui Pendidikan Jasmani Olahraga dan Kesehatan," Pendidik. Jasm. Indones., vol. 8, no. April, pp. 1-17, 2011.

[2] A. Paturusi, Manajemen Pendidikan Jasmani dan Olahraga. Jakarta: PT. Rineka Cipta, 2012.

[3] E. V. Reimers, Teacher Professional Development: An International Review of The Literature. International Institute for Educational Planning: UNESCO, 2003.

[4] W. Lee and D. L. Owens, Multimedia Based Instructional Design, Second Edi. Inc: United States of America, 2004.

[5] Y. Minkova, "Contemporery Multimedia Authoring Tools," Int. J. Eng. Sci. Comput., vol. 6, no. 10, 2020.

[6] A. Tanduklangi and C. Amri, Manajemen Sumber Daya Pembelajaran Bahasa Berbantuan Komputer (Computer Assisted Language Learning). Sleman: Deepublish, 2019.

[7] R. A. Pratama, "Media Pembelajaran Berbasis Articulate Storyline 2 Pada Materi Menggambar Grafik Fungsi Di Smp Patra Dharma 2 Balikpapan Learning Media Based On Articulate Storyline 2 On Drawing Function Graphs Lesson In Smp Patra Dharma 2 Balikpapan Pendahuluan Matemati," J. Dimens., vol. 7, no. 1, pp. 19-35, 2018.

[8] P. Arwanda, I. S, and A. A, "Pengembangan Media Pembelajaran Articulate Storyline Kurikulum 2013 Berbasis Kompetensi Peserta Didik Abad 21 Tema 7 Kelas IV Sekolah Dasar," Al-Madrasah J. Pendidik. Madrasah Ibtidaiyah, vol. 4, no. 2, pp. 193-204, 2020.

[9] S. Setyaningsih, Rusijono, and A. Wahyudi, "Pengaruh Penggunaan Media Pembelajaran Interaktif Berbasis Articulate Storyline Terhadap Motivasi Belajar Dan Hasil Belajar Siswa Pada Materi Kerajaan Hindu," J. Pendidik. dan Ilmu Pengetah., vol. 20, no. 2, pp. 144-156, 2020.

[10] D. Sapitri, "Pengembangan Media Pembelajaran Berbasis Aplikasi Articulate Storyline Pada Mata Pelajaran Ekonomi Kelas X SMA," Inovtech, vol. 2, no. 01, 2020.

[11] S. Mallu and S. Samsuriah, "Implementasi Articulate Storyline dalam Pembuatan Bahan Ajar Digital pada STMIK Profesional Makassar," in Seminar Nasional Teknik Elektro dan Informatika (SNTEI), 2020, pp. 102-104.

[12] Munrir, Multimedia Konsep Dan Aplikasi Dalam Pendidikan. Bandung: Alfabeta, 2015. 